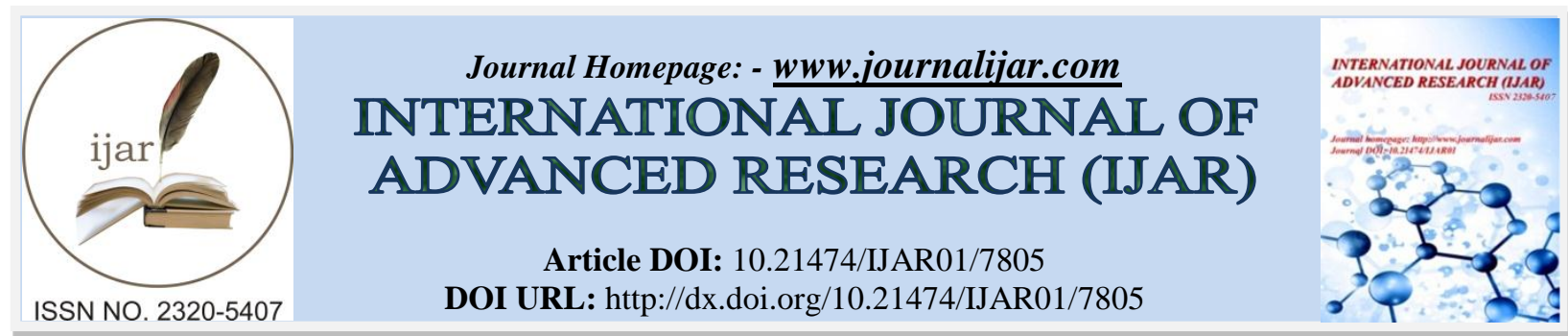

RESEARCH ARTICLE

\title{
THE EFFECT OF SELF-EFFICACY AND OBEDIENCE PRESSURE ON AUDIT JUDGMENT BY USING TASK COMPLEXITY AND MORAL REASONING AS THE MODERATING VARIABLE
}

1. Magister of Accounting, Hasanuddin University, Indonesia.

2. Economics and Business Faculty, Hasanuddin University, Indonesia.

\section{Manuscript Info}

Manuscript History

Received: 4 August 2018

Final Accepted: 6 September 2018

Published: October 2018

\section{Keywords:}

self-efficacy, obedience pressure, task complexity, moral reasoning, audit judgment.

\section{Abstract}

Ensuring that the implementation of good governance activities was necessary for functional supervision in the government that can be carried out by internal and external auditors. This study aims to provide a review of the determinant factors in influencing the audit judgment of the government's external auditor. As many as 58 auditors from the State Audit Board of the Republic of Indonesia Representative of Southeast Sulawesi Province were sampled in this study. Data collection using a questionnaire instrument. And data were analyzed using Moderated Regression Analysis (MRA). The results of this study showed that (1) self-efficacy has a significant effect on audit judgment, (2) the obedience pressure has a significant effect on audit judgment, (3) the task complexity moderates the relationship of self-efficacy on audit judgment, positive-signed regression coefficients that indicate that the task complexity strengthens the relationship of self-efficacy on audit judgment, (4) the task complexity moderates the relationship of obedience pressure on audit judgment. Positive-signed regression coefficients that indicate that the task complexity strengthens the relationship of obedience pressure on audit judgment, (5) Moral reasoning does not moderate the relationship of self-efficacy to audit judgment, and (6) Moral reasoning moderates the relationship of obedience pressure on audit judgment. The regression coefficient is negative, indicating that the existence of moral reasoning weakens the relationship of obedience pressure on audit judgment. Originality for this paper shows as: conduct a research about task complexity and moral reasoning of auditor external in governmental sector in producing the audit judgment especially in Southeast Sulawesi Province in Indonesia, and this research retest the research result from Jackman and Oldham (1980), Cohen et al. (2001), Jamilah et al. (2007), Iskandar and Sanusi (2011); Yuliani (2012); Sanusi et al. (2015); and Nursaid (2016). Based on these, researcher use model combination and quantitative approach.

Copy Right, IJAR, 2018,. All rights reserved. 


\section{Introduction:-}

So far the public sector in Indonesia always seizes the public's attention on accusations of corruption, collusion, nepotism, inefficiency and a source of state waste. The government as a public sector is not spared from this accusation, even though the government public sector organizations are institutions that run the wheels of government whose source of legitimacy comes from the community (Sulila, 2008). Conditions like this further increase the awareness of users of government financial statements to demand transparency in the use of funds in government administration. To increase the confidence of the users of financial statements, the financial statements need to be examined by a free and impartial financial audit body (BPK), as stipulated in Article $23 \mathrm{E}$ of the Constitution of the Republic of Indonesia.

One of the duties of the BPK auditor is to make judgment quality. Judgment as a congenitive process which is a decision-making behavior. Judgment as a continuous process of obtaining information (including feedback from previous actions), choice to act or not act, acceptance of further information (Hogarth, 1992).

In producing a judgment there are many factors that influence it, both textical and non-technical. Aspects of individual behavior are also considered to be very influential in making audit judgment (Arifuddin, 2014). Some factors that influence audit judgment that are examined in this study are self-efficacy and obedience pressure. Selfefficacy itself comes from social cognitive theory, introduced by Bandura (1986) which states that individual performance is not only influenced by their environmental factors but also influenced by motivational factors (personal self-efficacy). Self-efficacy is an individual's assessment of self-confidence in his ability to carry out tasks so as to obtain results that are as expected (Bell and Kowlozski, 2002). Individuals with high self-efficacy tend to perform well on various tasks (Bandura, 1997; Stajkovic and Luthans, 1998a). Whereas, individuals with low selfefficacy tend to avoid tasks and situations that they believe exceed their abilities (Sanusi et al., 2015). Thus, it can be said that an auditor who has high self-efficacy in himself can do his job and responsibilities as a good auditor.

Several previous studies have examined the effect of self-efficacy on audit judgment. In the research of Iskandar and Sanusi (2011) stated that auditors with high self-efficacy affect the performance of audit judgment rather than auditors who have low self-efficacy. This is also supported by several other studies such as Trianevant Research (2014); Sanusi et al. (2015), Suwandi (2015) and Suardikha and Budianrtha (2017) state that positively self-efficacy influences audit judgment, because auditors who have high self-efficacy will feel confident and confident that they can perform audit tasks as well as possible.

In carrying out audit tasks, auditors sometimes have obedience pressure. This is obtained from the pressures of superiors, auditees, and co-workers so that the auditor behaves deviantly from the existing professional standards when carrying out his duties. Lord's findings and Dezoort (2001) see the influence of supervisory pressure on consequences that require costs, such as lawsuits, loss of professionalism and loss of public trust and social credibility. Conversely auditors with low professional commitment will have the potential to behave dysfungsional (eg, prioritizing client interests) (Kusumawati and Syamsuddin, 2018). This indicates the influence of the supervisor's pressure on the judgment taken by the auditor. The results of research by Jamilah et al. (2007); Yustrianthe (2012); Yuliani (2012); Drupadi and Sudana (2015), Yendrawati and Mukti (2015) and Hafid (2016) state that obedience pressure has a significant effect on audit judgment. The pressure received by auditors from superiors and entities with the intention that the auditor carry out orders or wishes of his supervisor or client.

In this study also used two moderating variables with the consideration that both of these variables can strengthen or weaken the influence of self-efficacy and adherence pressure on audit judgment. The two variables are task complexity and moral reasoning.

Hackman and Oldham (1980) research results show that one of the factors that influence audit judgment was the complexity of the task. Task characteristics are an integral part of performance assessment. In line with Abdolmohammadi and Wright (1987) which states that there are differences in judgment taken by the auditor on high complexity and low complexity, the existence of high complexity will affect the results and performance of audit judgment. Task characteristics in several studies were designed as moderators for information management work and decision making (Peterson \& Bownas, 1982; Fleishman, 1975). The results of the research by Wood R.E, Mento, A.J and Locke E.A (1987) show that the task complexity variable is a moderator variable that is significant to the performance relationship. Locke et al. (1984) describe that task complexity moderates the relationship between self-efficacy and performance. As well as the results of Arifuddin's research (2014) stated that the 
complexity of the task can moderate the relationship of effort with audit judgment. On the other hand, Libby (1995) states that the complexity of tasks can be used as a tool in improving the quality of work. With complex and diverse tasks, it will help auditors to better understand the tasks they are working on so as to produce better consideration.

Subsequent moderation used by this research is moral reasoning. Moral reasoning in this study is used as a control belief that can facilitate or hinder the performance of behavior and perceived strength of factors that support or inhibit individual behavior. Kohlberg (1982) explains that the level of moral reasoning development or moral reasoning is influenced by three things, namely age, level of education and environmental conditions.

According to Graffikin and Lindawati (2012) moral reasoning is defined as the reason underlying someone in carrying out an action or reason underlying someone in justifying or criticizing an act (good or wrong). The results of research by Cohen et al (2001) that moral reasoning shows can be associated with other variables in the study. As well as Haron et al. (2015) states that moral reasoning has a significant effect on ethical considerations of auditors. This study also states that these findings will be useful for governments, regulators and frms audits that seek to improve the ethics of their auditors. And the study of Mindarti et al. (2016) found that moral reasoning affects audit, in this case the audit process and produces audit quality. And Lord and DeZoort's (2001) research shows that auditors at lower levels of moral development become more vulnerable to obedience and conformity pressure than auditors at higher stages of moral development. This shows moral reasoning as a matter of controller in carrying out tasks performed by someone.

Based on the description above, this study was conducted to test and re-analyze the factors of self-efficacy, pressure of obedience, and auditor independence towards audit judgment that had been carried out by Iskandar and Sanusi (2011); Yuliani (2012); Sanusi et al. (2015); and Nursaid (2016), and Alamri et al. (2017) by adding task complexity and moral reasoning as moderating. Moderating task complexity and moral reasoning is added with the hope that by moderating this can show more consistent results in examining the auditor's ability to produce judgment.

\section{Literature Review and Hypotheses \\ Cognitive Social Theory}

Social cognitive theory was introduced by Bandura in 1986, which was the development of Bandura's social learning theory in 1977. According to Bandura (1977), the process of observing and imitating behavior, the attitude of others as a model is an act of learning. This learning theory from Bandura seems to be generally applicable in all steps of social, communication, information, and instructional education in formal and informal environments.

Social cognitive theory is used to identify and predict individual and group behavior and identify appropriate methods to change the behavior. This theory is closely related to one's learning to be a better person. This theory explains that in learning, knowledge, personal experience, personal characteristics interact (Bandura, 1986).

In Bandura's theory (1986) formulates self-regulating cognitive mechanisms related to effort. Efforts that exist in individuals reach the level of performance they believe in. In particular, self-efficacy, or a person's belief whether he can take the actions needed to achieve a level of performance on a particular task. Self-ability is focused on goal setting as a fundamental way to regulate one's behavior, but allows other factors to influence. With cognitive and motivational mechanisms including determining goals, expectations and increasing the use of high quality problem solving strategies. So, when the auditor has a high self-efficacy on him, the judgment that is produced because there is confidence in him in producing a quality judgment

\section{Theory of Planned Behaviour}

The theory of planned behavior (TPB) is an extension of the theory of reasoned action (TRA). Icek Ajzen developed this TPB theory in 1985 by adding a construct called perceived behavioral control to regulate the control behavior of individuals which is limited by the shortcomings and limitations of the lack of resources used for behave (Ajzen, 1991). This concept proposed by Ajzen (1985) aims to improve the predictive power of the TRA theory by incorporating perceived controls. The purpose and benefits of this theory is to predict and understand the effects of behavioral motivation, both the individual's own will and not the individual's will.

The theory of planned behavior (TPB) by Ajzen is designed to relate to behaviors where people have a high level of control over their will (valitional control) and assume that all behavior is the domains of personal and social psychology (Ajzen, 1991) 
It should be noted that the theory of planned behavior is not directly related to the amount of control that is actually owned by a person, but this theory is more considering the possible effects of perceived behavioral control in achieving behavioral goals. If the intention is to show someone's desire to try certain behaviors, perceived control is more to consider some realistic constraints that might occur.

As has been explained about the theory of planning behavior, in behaving a person is directed by several things or beliefs. Similarly with the auditor, in behaving in this context makes judgment, influenced by these things.

Intervention of events according to TPB theory can result in changes in actions or perceptions of behavior control, with the effect that actual actions no longer allow accurate predictions of individual behavior. The pressure of obedience given by both the supervisor and the auditee and the complexity of the audit task carried out are external incentives received by the auditor. An auditor has the belief that there will be good things that facilitate and things that obstruct him in making judgment professionally. In this case, the pressure of obedience and complexity of the audit task become things that can hinder the auditor to produce judgment professionally.

In the perceived control in producing a behavior, one of which is included is moral reasoning. Moral reasoning is considered as a control that is perceived by control trust that can facilitate or hinder the performance of behavior and perceived strength of factors that support or inhibit a person's behavior.

\section{Moral Development Theory}

The theory of moral development that is often used in ethical level research is Kohlberg's model. This theory has the view that moral reasoning is the basis of ethical behavior. According to Kohlberg (1971) the stages of moral development were a measure of a person's moral level based on the development of moral reasoning. Kohlberg conducts research based on a case of moral dilemma to observe differences in individual behavior in addressing the same moral issues. Then Kohlberg made a classification of the responses of each individual into six different stages. There are three stages of moral development, namely the pre-conventional stages, conventional stages and postconventional stages.

In the first stage (pre-conventional) which is the lowest stage, individuals will tend to act due to submission and fear of the existing law. In addition, individuals at this moral level will also view their personal interests as the main thing in doing an action. In the second stage (conventional), individuals have a basis for moral considerations related to understanding the law, social rules in society, obligations, and justice in their social environment. Individuals at this stage begin to form moral reasoning in themselves by obeying rules such as ethical rules, professional codes of ethics to avoid dysfunctional behavior. Meanwhile at the highest stage (post-conventional), individuals have shown higher moral management maturity. Moral maturity is the basis for individual consideration when addressing ethical issues related to the behavior of social responsibility for others.

Hypotheses

Self-efficacy is a perception or belief about one's own abilities. Bandura (1993) states that self-efficacy is a person's belief that he can carry out a task at a certain level, which affects personal activity towards achieving goals. Furthermore, this relationship will also show a relationship with performance (Locke and Latham, 1990).

Generally self-efficacy shows a significant positive relationship with performance (Chen et al., 2000; Philips and Gully, 1997 in Nadhiro, 2010). For example Stajkovic and Luthans (1998b) reported a relationship between selfefficacy and performance with an average correlation of 0.38 while Locke and Latham (1990) the relationship of these two variables had an average correlation of 0.42. In the research of Iskandar and Sanusi (2011) and Sanusi et al. (2015) states that auditors with high self-efficacy affect the performance of audit judgment rather than auditors who have low self-efficacy. However, Nadhiro (2010) states that self-efficacy has no effect on judgment, it is because self-efficacy and performance are influenced by rewards for their ability, if the reward is given low, high self-efficacy has no effect on its performance. In accordance with Bandura's social cognitive theory (1986) that belief in one's own abilities will influence the results of their work. The hypothesis proposed is as follows:

H1. Self-efficacy has a significant effect on audit judgment.

Intervention of events according to TPB theory can result in changes in actions or perceptions of behavior control, with the effect that actual actions no longer allow accurate predictions of individual behavior. The pressure of good 
adherence given by superiors and auditors from the audit duties carried out is an external impulse received by the auditor.

Obedience pressure leads to pressure obtained from superiors and also the pressure gained from the audited entity. Differences in expectations between auditee with auditors are things that cause compliance pressure to occur. When the difference in expectations occurs, the entity being audited will try to pressure the auditor to equalize expectations. Then there will be a conflict between the auditor and the entity. When this conflict occurs, pressure arises from the boss. This boss's pressure can be an order to deviate from a predetermined standard. This is consistent with the results of Jamilah et al. (2007), Yustrianthe (2012); Yuliani (2012), Tatiwakeng (2013), states that compliance pressure affects audit judgment. However, Daljono (2012) research states that the pressure of obedience does not affect audit judgment. The hypothesis proposed is as follows:

H2. Obedience pressure has a significant effect on audit judgment.

According to Stajkovik and Luthans (1998b) states that task complexity moderates the effect of self-efficacy on individual performance. And auditors specifically make judgment and decisions involving tasks with various variations of task complexity. Research conducted by Sanusi et al. (2015) stated that self-efficacy affects audit performance with low task complexity.

With the self-efficacy of the auditor, he can carry out a task at a certain level. Bandura (1993) states that selfefficacy is the belief that a person can carry out a task at a certain level, which affects a person's activities towards achieving goals. According to Libby (1995) that task complexity can be used as a tool in improving the quality of work. With complex and diverse tasks, it will help auditors to better understand the tasks they are working on so as to produce better consideration. The hypothesis proposed is as follows:

H3. The task complexity moderates the effect of self-efficacy on audit judgment.

In the TPB theory there are three beliefs including normative beliefs, namely the belief about normative expectations of others and the motivation to approve these expectations. According to the TPB theory the behavior a person acquires is like an intervention, the pressure of the situation can result in changes in actions or perceptions of behavior control, with the effect that actual actions no longer allow accurate predictions of individual behavior (Ajzen, 1991). The pressure of obedience given by both the supervisor and the auditee and the complexity of the audit task carried out are external incentives received by the auditor. An auditor has the belief that there will be good things that facilitate and things that obstruct him in making judgment professionally. In this case, the pressure of obedience becomes a matter that can hinder the auditor to produce judgment professionally.

The level of task difficulty and task structure are two aspects of the compiler in the complexity of the task and in relation to the level of difficulty the task is always associated with the amount of information about the task, while the structure is related to information clarity (Jamilah, et al, 2007). This means that the task structure provides clear and complete information to make appropriate consideration in decision making. Meanwhile, difficult and complex tasks allow a person to feel difficulty with the task at hand.

The existence of pressures faced by the auditor coupled with the complexity of the task is expected to greatly affect the auditor's judgment. Although according to Libby (1995) that task complexity can be used as a tool in improving the quality of work. With complex and diverse tasks, it will help auditors to better understand the tasks they are working on so as to produce better consideration. However, if the pressure obtained and the inability of the auditor to avoid such pressure can affect the results of the judgment auditor. In relation to auditing activities, the high complexity of the audit can cause auditors to behave dysfunctionally. The existence of high task complexity can damage the judgment made by the auditor. The hypothesis proposed is as follows:

H4. The task complexity moderates the effect of compliance pressure on audit judgment.

Cognitive social theory (Bandura, 1986, 1993) formulates self-regulating cognitive mechanisms related to effort. Efforts that exist in individuals reach the level of performance they believe in. In particular, self-efficacy, or a person's belief whether he can take the actions needed to achieve a level of performance on a particular task. Selfability is focused on goal setting as a key way to regulate one's behavior, but allows other factors to influence.

In TPB theory, there is a control belief that can facilitate or hinder the performance of behavior and perceived strength of factors that support or inhibit individual behavior in this case moral reasoning. Sometimes, an auditor 
feels trust in their own low ability because of things that affect their beliefs like a task that is faced hard and unable to carry out an audit consistently.

On the other hand, if the auditor has self-efficacy regarding the belief in high self-ability, all tasks can be overcome. The existence of moral reasoning in solving problems increases a person's confidence in carrying out a job because it will lead to satisfaction in him in carrying out his duties well. Related to this, the auditor's ability to make the judgment better. The hypothesis proposed is as follows:

H5. Moral reasoning moderates the effect of self-efficacy on audit judgment.

Praditaningrum and Januarti (2012) states that compliance pressure factor is one of the factors that can influence audit judgment. An auditor continually faces an ethical dilemma involving choices between conflicting values, pressure from obedience from superiors or audited entities that can affect the audit process conducted by the auditor. The theory that supports it is the theory of obedience.

According to Kohlberg (1971) the stages of moral development are a measure of a person's moral level based on the development of moral reasoning. The results of the studies of Throne and Hartwick (2001) show that auditors have higher values of moral reasoning after prescriptive discussions with peers and lower values of moral reasoning after deliberative discussion with peers demonstrates the importance of discussions about debated dilemmas with colleagues and the importance of the type of discussion to predict and explain the auditor's moral reasoning. More specifically, the results show that discussions with colleagues can provide information and / or signals of what is important and acceptable for the resolution of moral dilemmas, which facilitate the transformation of the auditor's moral reasoning. This shows the importance of informal mechanisms, such as peer discussions, as part of the social control system.

The existence of a moral dilemma, namely the pressure of obedience can affect judgment. Thus, with the moral reasoning possessed by auditors will be able to maintain their consistency in carrying out audits and provide judgment (Rasmussen and Windsor, 2003), because there is control that is understood by the auditor of the work done to not deviate and not violate the ethics of his work as an auditor. The hypothesis proposed is as follows:

H6. Moral reasoning moderates the effect of compliance pressure on audit judgment.

\section{Methodology:-}

The approach used in this study is a quantitative approach, which includes quantitative analysis to test between theory and factuality by first setting a hypothesis and then testing with statistical analysis techniques. The object in this study was conducted at the Office of the Republic of Indonesia Representative Office of Southeast Sulawesi Province. The total population in this study was 58 people. The sampling technique in this study uses census methods, namely questionnaires conducted on all populations. The analysis model used to test hypotheses is to use Moderated Regression Analysis (MRA). Operational definitions and measurements for the variables in this study were:

1. Audit Judgment is the auditor's policy in determining opinions about the audit results which refers to the determination of an idea, opinion or estimate about an object, status or other event (Susetyo, 2009). This variable is measured using an instrument that refers to Susetyo's research (2009) which has developed a case overview of Jenkins and Haynes (2003).

2. Task complexity (Z1) is defined by the number of tasks faced by auditors, different and interrelated with each other (Jamilah et al., 2007). Task complexity can arise from the ambiguity of the task at hand. The complexity of the task is able to improve the quality of work results depending on the level of complexity of the task at hand. With complex and diverse tasks, it can help auditors to better understand the tasks they are doing so as to produce better consideration.

3. Moral reasoning (Z1) refers to the process experienced by an individual in determining the good or bad, right or wrong that influences him in making a decision (Jusup, 2001). For moral reasoning, using the Multidimensional Ethics Scale (MES) by Cohen at al., 2001 and has been developed by Januarti and Faisal (2010) in measuring a person's moral reasoning in action. There are five indicators of measuring moral reasoning including Justice or moral equity, Relativism, Egoism, Utilitarianism, and Deontology or contractual.

4. Self-efficacy (X1) is defined as the auditor's confidence or belief in their ability to carry out and complete a task at a certain level (Bandura, 1993). 7 statements related to self-efficacy refer to the statement developed by Kowlozski et al. (2001), and Bell and Kowlozski (2002). 
5. Obedience Pressure (X2) is defined as the pressure obtained by the auditor from superiors, colleagues, or the entity being examined. This pressure forces auditors to behave deviate from standards and affect auditor performance (Jamilah et al., 2007). Measurement indicators refer to Lord and Dezoort (2001).

\section{Results and Discussions:-}

Before testing the hypothesis, it is necessary to test the validity and reliability of the data, the results show that all statements in the self-efficacy, obedience pressure, task complexity, moral reasoning and audit judgment questionnaire are said to be valid. And the results of reliability testing data showed that self-efficacy was 0.842 , obedience pressure 0.612 , task complexity 0.710 , moral reasoning 0.732 , and audit judgment 0.734 , the value of reliable test results was above 0.60 (Cronbach Alpha standard) (Sekaran, 2016).

\section{Self-efficacy has a significant effect on audit judgment.}

The test results show that the hypothesis proposed by H1 is accepted. Where is the significance level of 0.011 (sig. P $<0.05$ ) with a coefficient of 0.266 . Thus the hypothesis that self-efficacy has a significant effect on audit judgment is empirically proven. In this case a positive direction is also obtained.

The results of this study are in accordance with the social cognitive theory by Bandura (1986) which states that selfefficacy is the belief or belief that a person has in carrying out a task will affect personal activity towards achieving goals. In this case, auditors who have confidence in carrying out audit assignments are able to influence their work and goals, including in decision-making activities, namely audit judgment on the examination carried out.

The results of this study are also supported by the results of Chen et al. (2000) research which states that generally self-efficacy shows a significant positive relationship with performance. This is also in line with Iskandar and Sanusi (2011) that auditors with high self-efficacy affect the quality of audit auditor judgment rather than auditors who have low self-efficacy. As well as Sanusi et al. (2015) and Suwandi (2015) state that self-efficacy has a significant effect on audit judgment.

\section{Obedience pressure has significant effect on audit judgment.}

The test results show that the hypothesis proposed by $\mathrm{H} 2$ is accepted. Where is the significance level 0.004 (sig. P $<0.05$ ) with a coefficient of 0.390 . Thus the hypothesis which states that obedience pressure has a significant effect on audit judgment is empirically proven. In this case a positive direction is also obtained. This can be explained that the pressure of obedience can increase if the respondent in this case the auditor does not fulfill the client's desire to deviate from professional standards if he does not want to have problems with the client / auditee, the auditor will obey the wishes of the auditee even though it is in accordance with professional standards. But the pressure of obedience itself is not only found in the auditee but can also come from superiors who put pressure on work. According to Jamilah et al. (2007) in his article argues regarding views related to obedience that individuals who have power are a source that can influence the behavior of others with the commands they give.

The results of this study are in accordance with the theory of planned behavior (TPB) where the intervention of events according to TPB theory can produce changes in actions or perceptions, with the effect that changes in actual actions no longer allow accurate predictions of individual behavior. Obedience pressures both given by superiors and auditors from the audit duties carried out are external incentives received by the auditor in influencing their behavior or actions.

The results of this study were also supported by Jamilah et al. (2007) states that compliance pressure affects audit judgment. This shows that the obedience pressure, namely orders from superiors and the desire of the auditee to deviate from professional standards, will tend to obey the order even though the order is inappropriate and contradicts professional standards. The same thing is also supported by other researchers such as Yustrianthe (2012); Yuliani (2012), Tatiwekang (2013), Agustini and Merkusiwati (2016) which states that compliance pressure has a significant effect on audit judgment.

Task complexity moderates the effect of self-efficacy on audit judgment.

The test results show that the hypothesis proposed by $\mathrm{H} 3$ is accepted. Where the significance level is 0.007 (sig. P $<0.05$ ) with a coefficient of 0.074 . The significance of the complexity of the task moderates the relationship between the obedience pressure with audit judgment can be proven. This finding also shows that task complexity can significantly strengthen the effect of self-efficacy on audit judgment. This shows that the high complexity of tasks 
influences the effect of self-efficacy on audit judgment auditors also increasing. The high complexity of the task when coupled with individual self-confidence will help in completing and achieving goals, one of which is giving consideration in the audit process that assists the auditor in issuing opinions as the final objective of the examination.

It is said in social cognitive theory that self-efficacy is a person's belief that he can carry out a task at a certain level, which affects personal activity towards achieving goals (Bandura, 1993). This result is in line with Stajkovik and Luthans (1998b) which states that task complexity moderates the effect of self-efficacy on individual performance. And auditors specifically make judgment and decisions involving tasks with various variations of task complexity. This is also in line with research conducted by Sanusi et al. (2015) stated that self-efficacy affects audit performance with low task complexity. . This research also proves the research of Wood R.E, Mento, A.J and Locke E.A (1987) that the task complexity variable is a moderator variable that is significant to the performance relationship.

\section{Task Complexity moderates the effect of obedience pressure on audit judgment.}

The test results show that the hypothesis proposed by H4 is accepted. Where is the significance level 0.005 (sig. $\mathrm{P}$ $<0.05$ ) with a coefficient of 0.163 . The meaning of the complexity of the task moderates the relationship between the pressures of compliance with audit judgment can be proved. This finding also shows that task complexity can significantly strengthen the influence of compliance pressure on audit judgment. This shows that the high complexity of the task strengthens the influence of the pressure of obedience to the auditor's judgment.

Described in the TPB theory, the behavior obtained by someone is like an intervention, the pressure of the situation can result in changes in actions or perceptions of behavior control, with the effect that actual action no longer allows accurate predictions of individual behavior (Ajzen, 1991). The pressure of obedience and the complexity of the audit task carried out is an external impulse received by the auditor. An auditor has the belief that there will be good things that facilitate and things that obstruct him in making judgment professionally. In this case, high task complexity and obedience pressure obtained become things that can hinder the auditor to produce judgment professionally.

Although according to Libby (1995) that task complexity can be used as a tool in improving the quality of work. However, if the pressure obtained and the inability of the auditor to avoid such pressure can affect the results of the judgment auditor. In relation to auditing activities, the high complexity of the audit can cause auditors to behave dysfunctional. This research also proves the research of Wood R.E, Mento, A.J and Locke E.A (1987) that the task complexity variable is a moderator variable that is significant to the performance relationship.

\section{Moral reasoning moderates the effect of self-efficacy on audit judgment.}

The test results show that the hypothesis proposed by H5 is rejected. Where is the significance level of 0.117 (sig. P> 0.05) with a coefficient of -0.204 . The meaning of moral reasoning moderates the relationship between selfefficacy and audit judgment that cannot be proven. This is indicated by a positive but insignificant coefficient value. The findings of this study indicate that self-efficacy is owned by the auditor even though it is supported by moral reasoning but has not provided a meaningful relationship to the auditor's judgment. Because according to Bandura (1993) where he formulates cognitive mechanisms that regulate the individual's self that relate to one's efforts in achieving certain goals. And where the efforts on individuals in achieving the level of performance that they believe will be able to achieve a level of performance on a particular task, self-confidence that is focused on goal setting as the main way to regulate one's behavior.

Based on the explanation above, it can be said that self-efficacy is considered sufficient to give a good influence on audit judgment. This has also been supported in the previous hypothesis 1 which states that self-efficacy has a significant effect on audit audits. So, quality judgment cannot be moderated by moral reasoning associated with selfefficacy, so that is the reason for rejecting the hypothesis that has been proposed.

\section{Moral reasoning moderates the effect of obedience pressure on audit judgment.}

The test results show that the hypothesis proposed by H6 is accepted. Where is the significance level of 0.04 (sig. P $<0.05$ ) with a coefficient of -0.237 . The meaning of moral reasoning moderates the relationship between the pressures of obedience to audit judgment can be proved. This finding also shows that moral reasoning can 
significantly weaken the influence of obedience pressure on audit judgment. This shows that the high moral reasoning weakens the relations of obedience pressure to audit judgment of BPK RI auditors of the representatives of Southeast Sulawesi Province.

According to Lord and DeZoort (2001) which shows that auditors at lower levels of moral development become more vulnerable to obedience and conformity pressure than auditors at higher stages of moral development.

The results of this study are in line with the TPB theory in the third dimension of the theory, namely the perceived control in producing a behavior, one of which is moral reasoning. Moral reasoning is considered as a control that is perceived by control trust that can facilitate or hinder the performance of behavior and perceived strength of factors that support or inhibit a person's behavior. And, with the control that is understood by the auditor the work done not to behave defiantly and not violate the ethics of his work as an auditor.

This research is also in line with Kohlberg's (1971) theory of moral development in which the stages of moral development are a measure of a person's moral level based on the development of moral reasoning. The results of the studies of Throne and Hartwick (2001) show that auditors have higher values of moral reasoning after prescriptive discussions with peers and lower values of moral reasoning after deliberative discussion with peers demonstrates the importance of discussions about debated dilemmas with colleagues and the importance of the type of discussion to predict and explain the auditor's moral reasoning. More specifically, the results show that discussions with colleagues can provide information and / or signals of what is important and acceptable for the resolution of moral dilemmas, which facilitate the transformation of the auditor's moral reasoning. This shows the importance of informal mechanisms, such as peer discussions, as part of the social control system.

The results of this study are also in line with the research of Rasmussen and Windsor (2003) that the moral reasoning possessed by auditors will be able to maintain their consistency in carrying out audits and providing judgment. Moral reasoning can suppress a person's moral dilemma in any situation to be awake in carrying out a task. Based on the results of this study, it can be concluded that moral reasoning significantly moderates and weakens the influence of obedience pressure on audit judgment. This means that the higher moral reasoning will influence and weaken the relationship of obedience to the auditor's judgment.

\section{Conclusions and Recommendations:-}

Self-efficacy has a significant effect on audit judgment, obedience pressure has a significant effect on audit judgment, the complexity of the task moderates and strengthens the relationship of self-efficacy to audit judgment, the complexity of the task moderates and strengthens the relationship of obedience pressure to audit judgment, moral reasoning does not moderate the relationship of self-efficacy towards audit judgment, and moral reasoning moderate and weaken the relationship of obedience pressure to audit judgment.

It is suggested to add other variables that are feasible to be used to determine the audit judgment quality that has not been mentioned in this study. The sample used in this study is still limited to one office of the Indonesian government's external auditor. So the next researcher is advised to further expand the scope of the research. The researcher can then retest the model used in this study.

\section{References:-}

1. Abdolmohammadi, M. dan Wright, A. 1987. An Examination of The Effect of Experience and Tax Complexity on Audit Judgment. The Accounting Review, 62 (1), pp 1-13.

2. Ajzen, Icek. 1985. from intentions to actions: A theory of planned behavior. In J. Kuhl \& J. Beckmann (Eds.), Action-control: From cognition to behavior (pp. 1 1-39). Heidelberg: Springer.

3. Ajzen, Icek. 1991. The Theory of Planned Behavior, Organizational Behavior and Human Decision Process, Vol. 50, pp. 179-211.

4. Arifuddin. 2014. The Effect of Performance Incentive on Audit Judgment By Using The Effort as The Intervening Variable and The Task Complexity as The Moderating Variable. IJABER, Vol. 12, No. 4, pp: 1305-1314.

5. Bandura, A. 1977. Sosial Learning Theory. New York: General Learning Press.

6. Bandura, A. 1986. Social Foundations of Thought and Action: A Social Cognitive Theory. Englewood Cliffs, NJ: Prentice-Hall. 
7. Bandura, A. 1993. Perceived Self-efficacy in Cognitive Development and Functioning. Educational Psychologist, 28(2), 117-148.

8. Bell, B. S. and Kozlowski, S. W. 2002. Goal orientation and ability: Interactive effects on selfefficacy, performance, and knowledge. Journal of Applied Psychology, Vol. 87 No. 3, pp. 497-505.

9. Chen, G., Gully, S. M., Whiteman, J. and Kilcullen, R. N. 2000. Examination of relationships among trait-like individual differences, state-like individual differences, and learning performance. Journal of Applied Psychology, Vol. 85 No. 6, pp. 835-847

10. Cohen, Jeffrey R., Lisa Milici Gaynor, Ganesh Krishnamoorthy, and Arnold M. Wright. 2011. The Impact on Auditor Judgments of CEO Influence on Audit Committee Independence. Auditing: A Journal Of Practice dan Theory, 30 (4):89-100.

11. Cohen, J. D; Greene, J. D, Sommerville, R. B., Nystrom, L. E., \&. Darley, J. M. 2001. An fMRI investigation of emotional engagement in moral judgment. Science, 293, 2105-2108.

12. Daljono, Seni Fitriani. 2012. Pengaruh Tekanan Ketaatan, Kompleksitas Tugas, Pengetahuan, dan Persepsi Etis Terhadap Audit Judgment. Jurnal Akuntansi, Vol 1, No. 1.

13. Drupadi, Made Julia dan Sudana, I Putu. 2015. Pengaruh Keahlian Auditor, Tekanan Ketaatan dan Independesi pada Audit Judgment. E-Jurnal Akuntansi Universitas Udayana, Vol. 12 No. 3. ISSN: 2302-8556. Hal 623655.

14. Fleishman, E. A. 1975. Toward a taxonomy of human performance. American Psychologist, 30,1127-1149.

15. Gaffikin, Michael and ASL Lindawati. 2012. The Moral Reasoning of Public Accountants in the Development of a Code of Ethics: the Case of Indonesia. Australasian Accounting Business and Finance Journal, volume 6: $3-28$.

16. Hafid, Andi Qadriah. 2016. Pengaruh pengalaman, tekanan ketaatan, dan kompleksitas tugas terhadap audit Judgment APIP dengan etika auditor sebagai variable moderasi. Tesis. Universitas Hasanuddin. Makassar.

17. Haron, Hasnah, Ishak Ismail dan Aw Lo Na. 2015. The Effect of Moral Reasoning Exposure to Ethics and Perceived Ethical Climate on Ethical Judgment of Auditors in Malaysia. Asian Journal of Business and Accounting, Vol 8 (2).

18. Hogarth. R. M., dan H.J. Einhorn. 1992. Order Effects in Belief Updating: The Belief-Adjustment Mode. Cognitive Psychology 24: 1-55.

19. Iskandar, Takiah Mohd, dan Sanusi, Mohd Zuaraidah. 2011. Assesing The Effect Of Self-Efficacy And Taks Complexity On Internal Control Audit Judgment. AAMJAF, Vol. 7, No. 1 pp: 29-52.

20. Jamilah, S., Fanani, Z., dan Chandrarin, G. 2007. Pengaruh gender, tekanan ketaatan dan komplesitas tugas terhadap Audit Judgment. Symposium nasional akuntansi X, pp26-28.

21. Januarti, Indira dan Faisal. 2010. Pengaruh Moral Reasoning Dan Skeptisisme Profesional Auditor Pemerintah Terhadap Kualitas Audit Laporan Keuangan Pemerintah Daerah. Simposium Nasional Akuntansi XIII. Purwokerto.

22. Jenkins, J. Gregory and C. M. Haynes. 2003. The Persuasiveness of Client Preferences: An Investigation of the Impact of Preference Timing and Client Credibility. Auditing: A Journal of Practice \& Theory. Vol.22. No.1, March: 143 - 154.

23. Kohlberg, L. 1982. Essays on moral develop ent, Vol I: The philosophy of moral development. Harper \& Row, San Francisco.

24. Kozlowski, S. W. J., Gully, S. M., Brown, K. G., Salas, E., Smith, E. M. and Nason, E. R. 2001. Effects of training goals and goal orientation traits on multidimensional training outcomes and performance adaptability. Organizational Behaviour and Human Decision Processes, Vol. 85 No. 1, pp. 1-31.

25. Kusumawati, Andi, and Syamsuddin. 2018. The Effect of Auditor Quality to Professional Skepticsm and Its Relationship to Audit Quality. International Journal of Law and Management. Emerald Insight.

26. Kusumawati, Andi, Syamsuddin and Sri Sundari. 2017. External Auditor Professional Skeptics In Producing Audit Quality. International Journal of Economic Research, Vol. 14 Number 2.

27. Libby, R. and Luft, J. 1995. Determinants of judgment performance in accounting settings:ability, knowledge, motivation, and environment. Accounting, Organizations and Society, Vol. 18 No. 5, pp. 425-50.

28. Locke, E. A., Frederick, E., Lee, C, \& Bobko, P. 1984. The effect of self-efficacy, goals, and task strategies on task performance. Journal of Applied Psychology, 69, 241-251.

29. Lord, Alan T. dan F. Todd Dezoort. 2001. The Impact of Commitment and Moral Reasoning on Auditors' Responses to Social Influence Pressure. Accounting, Organizations and Society 26, pp 215-235.

30. Margaret, Agnes Noviriana dan Surya Raharja. 2014. Analisis Faktor-faktor yang Mempengaruhi Audit Judgment pada Auditor BPK RI. Diponegoro Journal of Accounting, Vol. 3 No. 2, pp. 1-13. 
31. Mindarti, Ceacilia Sri, Pancawati Hardiningsih, dan Rachmawati Meita Oktaviani. 2016. Moral Reasoning Memoderasi Kompetensi dan Independensi Terhadap Audit._Simposium Nasional Akuntansi XIX, Lampung.

32. Nadhiro, Siti Asih. 2010. Pengaruh Kompleksitas Tugas, Orientasi Tujuan dan Self- Efficacy terhadap Kinerja Auditor dalam Pembuatan Audit Judgment (Studi Pada Kantor Akuntan Publik di Semarang). UNDIP: Semarang.

33. Peterson, N. G., \& Bownas, D. A. 1982. Skill, task structure and performance acquisition. In M. D. Dunnette \& E. A. Fleishman (Eds.). Human performance and productivity (Vol. 1,pp. 49-105). Hillsdale, NJ: Erlbaum.

34. Phillips, J. M. and Gully, S. M. 1997. Role of goal orientation, ability, need for achievement, and locus of control in the self-efficacy and goal setting process. Journal of Applied Psychology, Vol. 82 No. 5, pp. 792802.

35. Praditaningrum, Anugrah Suci. 2012. Analisis Faktor-faktor yang Berpengaruh Terhadap Audit Judgment (Studi pada BPK RI Perwakilan Provinsi Jawa Tengah). Fakultas Ekonomi dan Bisnis, Universitas Diponegoro Semarang.

36. Rasmussen, Bent Warming dan Carolyn A. Windsor. Danish Evidence of Auditors' Level of Moral Reasoning and Predisposition to Provide Fair Judgments. Journal of Business Ethics 47: 77-87.

37. Sanusi, Mohd Zuaraidah; Iskandar, Takiah Mohd dan Saleh, Norman Mohd. 2015. Effects Of Goal Orientation, Self-Efficacy And Task Complexity On The Audit Judgment Performance Of Malaysian Auditors. Accounting, Auditing and Accountability Journal, Emerald Insight.

38. Sekaran, Uma and Roger Bougie. 2016. Research Methods for Business. Seventh Edition. United Kingdom: John Wiley and Sons.

39. Suardihka, I Made Sadha dan Ketut Budiartha. 2017. Kemampuan Gender Memoderasi Pengaruh Self-efficacy dan Kompleksitas Tugas pada Audit Judgment. Jurnal, Vol. 12, No. 3, ISSN 1978-6069.

40. Susetyo, Budi. 2009. Pengaruh Pengalaman Audit Terhadap Pertimbangan Auditor dengan Kredibilitas Klien Sebagai Variabel Moderating. Online (Tesis). Universitas Diponegoro. Semarang.

41. Stajkovic, A. D., \& Luthans, F. 1998a. Self-efficacy and work-related performance: A meta-analysis. Psychological Bulletin, 124, 240-261.

42. Sulila, Ismet. 2008. Audit Kinerja Sektor Publik. Jurnal Inovasi, Vol.5, No. 2.

43. Suwandi. 2015. Pengaruh Self-efficacy, Kecerdasan Emosional, Tekanan Ketaatan dan Kompleksitas Tugas terhadap Auditor Judgment Auditor (Studi Empiris pada KAP di Pekanbaru, Padang, dan Batam). Jom FEKON , Vol 2 No. 1.

44. Tatiwekeng, Cindy Westefina. 2013. Pengaruh Efikasi Diri, Kompleksitas Tugas, dan Audit Judgment terhadap Kualitas Audit Judgment Auditor Internal Pemerintah. Jurnal Online (tesis). Universitas Gadha Mada. Yogyakarta.

45. Triavenant, Marsha. 2014. Pengaruh Gender, Orientasi Tujuan, Self-efficacy, dan Pengalaman terhadap Audit Judgment (Survei pada 11 Kantor Akuntansi Publik di Jakarta). Bandung: Universitas Widyatama.

46. Throne, Linda dan Jon Hartwick. 2001. The Directional Effects of Discussion on Auditors' Moral Reasoning. Contemporary Accounting Research Vol. 18 No. 2 pp. 337-61.

47. Wood, R.E. 1986. Task Complexity, Definition of The Construct. Organizational Behaviour and Human Decision Prosess, pp: 60-82.

48. Yendrawati, Reni dan Mukti, Dheane Kurnia. 2015. Pengaruh Gender, Pengalaman Auditor, Kompleksitas Tugas, Tekanan Ketaatan, Kemampuan Kerja dan Pengetahuan Auditor terhadap Audit Judgment. Jurnal Inovasi dan Kewirausahaan, Vol. 4 No. 1, hal: 1-8.

49. Yuliani, Nur Laila. 2012. Tekanan Ketaatan, Kompleksitas Tugas, Independensi, Pengetahuan, dan Pengalaman Auditor terhadap Audit Judgment. Jurnal Akuntansi, 5 (3), hal 40-53.

50. Yusrianthe, Rahmawati Hanny. 2012. Kajian Empiris Audit Judgment pada Auditor. Media Riset Akuntansi, Vol. 2. No. 2, hal. 170-186.

51. Zulaikha. 2007. Pengaruh Interaksi Gender, Kompleksitas Tugas dan Pengalaman Auditor terhadap Audit Judgment (Sebuah Kajian Eksperimental Dalam Audit Saldo Akun Persediaan). Simposium Nasional IX. 